\title{
Review: Effect of drugs on human cough reflex sensitivity to inhaled capsaicin
}

\author{
Peter $\vee$ Dicpinigaitis ${ }^{1,2}$
}

\begin{abstract}
Capsaicin, the pungent extract of red peppers, has been used in clinical research for almost three decades. Capsaicin has gained favor as the provocative agent of choice to measure cough reflex sensitivity, as it induces cough in a safe, reproducible, and dose-dependent manner. One of the major uses of capsaicin cough challenge testing has been to evaluate the effect of a pharmacological intervention on the human cough reflex. The current review summarizes the published experience with capsaicin inhalation challenge in the evaluation of drug effects on cough reflex sensitivity. A notable contrast evident between studies demonstrating a drug effect (inhibition of cough reflex sensitivity) and those that do not, is the predominance of healthy volunteers as subjects in the latter. This observation suggests that subjects with pathological cough, rather than normal volunteers, comprise the optimal group in which to evaluate the effect of potential antitussive agents on human cough reflex sensitivity.
\end{abstract}

Keywords: Cough, Capsaicin, Antitussive, Respiratory tract infection, Asthma

\section{Introduction}

Capsaicin, the pungent extract of red pepper (capsicum), has gained widespread use as a research tool among clinical investigators, as it induces cough in humans in a safe [1], dose-dependent, and reproducible manner [2,3]. Capsaicin cough challenge in humans was first described in 1984 [4], and has since been used to evaluate the effect of numerous pharmacological agents on cough reflex sensitivity. Although many drugs have been shown to inhibit induced cough in the laboratory, others have failed to do so, including agents widely regarded as clinically effective antitussives.

\section{Methods}

A United States National Library of Medicine (PubMed) search was performed in September, 2012 using the search terms "cough" and "capsaicin" limited to human studies published in English. The abstracts of the 328 articles meeting those search criteria were reviewed and 56 studies were identified in which capsaicin cough challenge was employed to assess the effect of a pharmacological intervention on cough reflex sensitivity. Studies

\footnotetext{
Correspondence: pdicpin@gmail.com

${ }^{1}$ Albert Einstein College of Medicine and Montefiore Medical Center, Bronx, NY, USA

${ }^{2}$ Einstein Division/Montefiore Medical Center, 1825 Eastchester Road, Bronx,
} NY 10461, USA

\section{Biomed Central

in which a positive drug effect was demonstrated $(\mathrm{n}=33)$ are listed in Table 1 [5-37]; trials in which no effect was noted $(\mathrm{n}=30)$ are summarized in Table $2[4,10,12,17$ 19,35,37-59]. In seven of these studies, multiple drugs and/or multiple subject groups were evaluated, resulting in both positive and negative results in terms of assessment of drug activity. As the purpose of this review was to assess drug trials in which a potential therapeutic (antitussive) effect of a drug was being evaluated, studies demonstrating enhancement of cough reflex sensitivity by angiotensin-converting enzyme (ACE) inhibitors or other agents were excluded.

\section{Discussion}

This review has identified 33 studies in which a pharmacological intervention was demonstrated to inhibit cough reflex sensitivity to inhaled capsaicin in a variety of subject populations, thus supporting the role of cough challenge as a useful clinical tool in the evaluation of potential antitussives [3]. A striking difference between the studies showing a positive drug effect (Table 1), and those failing to demonstrate a change in cough reflex sensitivity (Table 2 ) is the predominant subject populations studied. Of the negative studies, $70 \%$ involved evaluation of healthy volunteers. Among the trials displaying a positive drug effect, only $27 \%$ evaluated healthy 
Table 1 Drugs shown to inhibit cough reflex sensitivity to capsaicin

\begin{tabular}{|c|c|c|c|c|}
\hline $1^{\text {st }}$ author & Ref. \# & Year & Drug & Subject population \\
\hline Wise P & [5] & 2012 & menthol & healthy volunteers \\
\hline Takemura M & [6] & 2012 & montelukast & cough-variant asthma \\
\hline Ekstrand $Y$ & [7] & 2011 & inhaled steroids & asthma \\
\hline Ishiura Y & [8] & 2010 & etodolac & sinobronchial syndrome \\
\hline Ishiura $Y$ & [9] & 2009 & etodolac & asthma \\
\hline Dicpinigaitis $\mathrm{P}$ & {$[10]$} & 2009 & guaifenesin & viral URI \\
\hline Davenport P & {$[11]$} & 2009 & nicotine & healthy smokers \\
\hline Dicpinigaitis $P$ & {$[12]$} & 2008 & tiotropium & viral URI \\
\hline Ishiura Y & {$[13]$} & 2008 & suplatast & atopic cough \\
\hline Ferrari M & [14] & 2007 & omeprazole & asthma + GERD \\
\hline Usmani O & {$[15]$} & 2005 & theobromine & healthy volunteers \\
\hline Shioya T & {$[16]$} & 2004 & epinastine & atopic cough \\
\hline Dicpinigaitis $\mathrm{P}$ & {$[17]$} & 2003 & guaifenesin & viral URI \\
\hline Ishiura Y & {$[18]$} & 2003 & carbocysteine & asthma \\
\hline Ishiura Y & [19] & 2003 & seratrodast & chronic bronchitis \\
\hline Shioya $\mathrm{T}$ & [20] & 2002 & suplatast & cough-variant asthma \\
\hline Dicpinigaitis $P$ & [21] & 2002 & zafirlukast & cough-variant asthma \\
\hline Ceyhan B & [22] & 2002 & oxolamine & COPD \\
\hline Dicpinigaitis $\mathrm{P}$ & [23] & 2000 & baclofen & cervical SCl \\
\hline Brightling C & [24] & 2000 & budesonide & eosinophilic bronchitis \\
\hline Dicpinigaitis $P$ & [25] & 1998 & baclofen & healthy volunteers \\
\hline Shioya $\mathrm{T}$ & {$[26]$} & 1998 & azelastine & asthma \\
\hline Dicpinigaitis $P$ & {$[27]$} & 1997 & baclofen & healthy volunteers \\
\hline Shioya T & {$[28]$} & 1996 & azelastine & cough-variant asthma \\
\hline Fujimura M & [29] & 1995 & indomethacin & asthma, chronic bronchitis \\
\hline Hargreaves M & [30] & 1995 & sodium cromoglycate & ACE-inhibitor cough \\
\hline Hansson L & {$[31]$} & 1994 & lignocaine & healthy volunteers \\
\hline Van Wyck M & [32] & 1994 & glycopyrrolate & ACE-inhibitor cough \\
\hline Cazzola M & [33] & 1993 & theophylline & ACE-inhibitor cough \\
\hline Foster G & [34] & 1991 & sulindac & healthy volunteers \\
\hline McEwan J & [35] & 1990 & sulindac & ACE-inhibitor cough \\
\hline Choudry N & [36] & 1990 & lignocaine & healthy volunteers \\
\hline Fuller $\mathrm{R}$ & {$[37]$} & 1988 & codeine,morphine & healthy volunteers \\
\hline
\end{tabular}

Abbreviations: URl-acute upper respiratory tract infection; GERD-gastroesophageal reflux disease; SCl-spinal cord injury; $A C E$-angiotensin-converting enzyme.

volunteers, while the majority (73\%) investigated various forms of pathological cough. Of note, multiple agents were shown to inhibit cough reflex sensitivity in pathological cough, while having no effect in healthy volunteers, including guaifenesin [10,17] and tiotropium [12] in cough due to acute viral upper respiratory tract infection (URI; common cold). The leukotriene receptor antagonist zafirlukast inhibited capsaicin-induced cough in subjects with cough-variant asthma [21], but not in stable asthmatics without cough and healthy volunteers [44]. Interestingly, gabapentin has recently been shown to improve cough-specific quality of life in patients with refractory chronic cough, without affecting cough reflex sensitivity [38]. This particular study highlights the concept that the optimal approach to the evaluation of a potential antitussive agent should be multifaceted, with cough reflex sensitivity measurement complementing other measures, such as objective cough counting and subjective symptom-based questionnaires.

Conspicuous in their absence from the list of agents having demonstrated the ability to inhibit cough reflex sensitivity to capsaicin during URI are codeine and dextromethorphan, two of the most commonly used agents worldwide for the treatment of cough due to the common cold [60]. The only agents demonstrating the ability to inhibit cough reflex sensitivity to capsaicin in healthy 
Table 2 Drugs shown not to inhibit cough reflex sensitivity to capsaicin

\begin{tabular}{|c|c|c|c|c|}
\hline $1^{\text {st }}$ author & Ref. \# & Year & Drug & Subject population \\
\hline Ryan M & [38] & 2012 & gabapentin & chronic cough \\
\hline Yousaf N & [39] & 2010 & erythromycin & chronic cough \\
\hline Dicpinigaitis $P$ & [10] & 2009 & benzonatate & viral URI \\
\hline Dicpinigaitis $P$ & [12] & 2008 & tiotropium & healthy volunteers \\
\hline Davenport P & {$[40]$} & 2007 & codeine & healthy volunteers \\
\hline Dicpinigaitis $\mathrm{P}$ & [41] & 2003 & fexofenadine & healthy volunteers \\
\hline Dicpinigaitis $P$ & [17] & 2003 & guaifenesin & healthy volunteers \\
\hline Ishiura Y & [18] & 2003 & ambroxol & asthma \\
\hline Ishiura Y & [19] & 2003 & pranlukast & chronic bronchitis \\
\hline Dicpinigaitis $P$ & {$[42]$} & 2001 & celecoxib & asthma \\
\hline Fujimura M & [43] & 2000 & mexiletine & healthy volunteers \\
\hline Dicpinigaitis $P$ & {$[44]$} & 1999 & zafirlukast & asthma without cough \\
\hline Capon D & [45] & 1996 & dextromethorphan & healthy volunteers \\
\hline Hansson L & {$[46]$} & 1994 & nicotine & healthy nonsmokers \\
\hline Hutchings $\mathrm{H}$ & [47] & 1994 & codeine & healthy volunteers \\
\hline O'Connell F & {$[48]$} & 1994 & clonidine & healthy volunteers \\
\hline Fujimura M & [49] & 1993 & procaterol & asthma, chronic bronchitis \\
\hline Choudry N & [50] & 1993 & MAO inhibitors & healthy volunteers \\
\hline Stone $\mathrm{R}$ & [51] & 1993 & 5-HT (serotonin) & healthy volunteers \\
\hline Fujimura M & {$[52]$} & 1992 & procaterol & healthy volunteers \\
\hline Ventresca P & [53] & 1992 & furosemide & healthy volunteers \\
\hline Karlsson J & {$[54]$} & 1992 & furosemide, HCTZ & healthy volunteers \\
\hline Studham J & {$[55]$} & 1992 & terfenadine & healthy volunteers \\
\hline Choudry N & {$[56]$} & 1991 & inhaled mu opioid agonist & healthy volunteers \\
\hline Smith C & {$[57]$} & 1991 & salbutamol, ipratropium & healthy volunteers \\
\hline Choudry N & {$[58]$} & 1991 & granisteron (5-HT3) & healthy volunteers \\
\hline McEwan J & [35] & 1990 & sulindac & idiopathic cough \\
\hline Hansson L & [59] & 1988 & nedocromil & healthy volunteers \\
\hline Fuller $\mathrm{R}$ & {$[37]$} & 1988 & inhaled opiates & healthy volunteers \\
\hline Collier J & [4] & 1984 & sodium cromoglycate & healthy volunteers \\
\hline
\end{tabular}

Abbreviations: URl-acute upper respiratory tract infection; MAO-monoamine oxidase; HCTZ-hydrochlorothiazide.

volunteers were theobromine [15], baclofen [25,27], inhaled lignocaine [31,36], sulindac [34], systemic opiates [37], menthol [5] and, in healthy smokers, nicotine [11]. Interestingly, this list includes drugs thought to be centrally acting antitussives, as well as agents whose cough-inhibiting properties are presumed to occur through a peripheral mechanism.

Limiting the evaluation of a potential modulator of cough reflex sensitivity to a study group of healthy volunteers, whose cough reflex is not hyperresponsive, may not allow the drug to demonstrate its inhibitory effect. Thus, subjects with pathological cough appear to comprise the optimal study population when evaluating the effects of a potential antitussive agent on cough reflex sensitivity. The particular type of pathological cough best suited for evaluation of a novel antitussive may depend on the specific pharmacological action of the drug, and currently remains a question under vigorous debate.

\section{Competing interests}

The author declares that he has no competing interest.

Received: 25 July 2012 Accepted: 9 October 2012

Published: 12 November 2012

\section{References}

1. Dicpinigaitis PV, Alva RV: Safety of capsaicin cough challenge testing Chest 2005, 128:196-202.

2. Dicpinigaitis PV: Short- and long-term reproducibility of capsaicin cough challenge testing. Pulm Pharmacol Ther 2003, 16:61-65.

3. Morice $A H$, Fontana GA, Belvisi MG, et al: European respiratory society guidelines on the assessment of cough. Eur Respir J 2007, 29:1256-1276.

4. Collier JG, Fuller RW: Capsaicin inhalation in man and the effects of sodium cromoglycate. Br J Pharmacol 1984, 81:113-117.

5. Wise PM, Breslin PA, Dalton P: Sweet taste and menthol increase cough reflex thresholds. Pulm Pharmacol Ther 2012, 25:236-241. 
6. Takemura M, Niimi A, Matsumoto H, Ueda T, Matsuoka H, Yamaguchi M, Jinnai M, Chin K, Mishima M: Clinical, physiological, and anti-inflammatory effect of montelukast in patients with cough variant asthma. Respiration 2012, 83:308-315.

7. Ekstrand Y, Ternesten-Hasseus E, Arvidsson M, Lofdahl K, Palmqvist M, Millqvist E: Sensitivity to environmental irritants and capsaicin cough reaction in patients with a positive methacholine provocation test before and after treatment with inhaled corticosteroids. J Asthma 2011 48:482-489

8. Ishiura Y, Fujimura M, Yamamoto H, Ohkura N, Myou S: Role of COX-2 in cough reflex sensitivity to inhaled capsaicin patients with sinobronchial syndrome. Cough 2010, 6:7.

9. Ishiura Y, Fujimura M, Yamamoto H, Ishiguro T, Ohkura N, Myou S: COX-2 inhibition attenuates cough reflex sensitivity to inhaled capsaicin in patients with asthma. J Invest Allergol Clin Immunol 2009, 19:370374.

10. Dicpinigaitis PV, Gayle YE, Solomon G, Gilbert RD: Inhibition of cough-reflex sensitivity by benzonatate and guaifenesin in acute viral cough. Respir Med 2009, 103:902-906.

11. Davenport PW, Vovk A, Duke RK, Bolser DC, Robertson E: The urge-to-cough and cough motor response modulation by the central effects of nicotine. Pulm Pharmacol Ther 2009, 22:82-89.

12. Dicpinigaitis PV, Spinner L, Santhyadka G, Negassa A: Effect of tiotropium on cough reflex sensitivity in acute viral cough. Lung 2008, 186:369-374.

13. Ishiura $Y$, Fujimura M, Yamamoto H, Nobata K, Ishiguro T, Ogawa H, Myou S: Effect of an orally active Th2 cytokine inhibitor, suplatast, on "atopic cough. Arzneimittelforschung 2008, 58:297-302.

14. Ferrari M, Benini L, Brotto E, Locatelli F, De lorio F, Bonella F, Tacchella N, Corradini G, Lo Cascio V, Vantini I: Omeprazole reduces the response to capsaicin but not to methacholine in asthmatic patients with proximal reflux. Scand J Gastroenterol 2007, 42:299-307.

15. Usmani OS, Belvisi MG, Patel HJ, Crispino N, Birrell MA, Korbonits M, Korbonits D, Barnes PJ: Theobromine inhibits sensory nerve activation and cough. FASEB J 2005, 19:231-233.

16. Shioya T, Satake M, Kagaya M, Sano MA, Watanabe A, Fukui S, Sasaki M: Antitussive effects of the $\mathrm{H} 1$-receptor antagonist epinastine in patients with atopic cough (eosinophilic bronchitis). Arzneimittelforschung 2004 54:207-212.

17. Dicpinigaitis PV, Gayle YE: Effect of guaifenesin on cough reflex sensitivity. Chest 2003, 124:2178-2181.

18. Ishiura Y, Fujimura M, Yamamori C, Nobata K, Myou S, Kurashima K, Michishita $Y$, Takegoshi T: Effect of carbocysteine on cough reflex to capsaicin in asthmatic patients. Br J Clin Pharmacol 2003, 55:504-510.

19. Ishiura Y, Fujimura M, Yamamori C, Nobata K, Myou S, Kurashima K, Takegoshi T: Thromboxane antagonism and cough in chronic bronchitis. Ann Med 2003, 35:135-139.

20. Shioya T, Satake M, Sano M, Kagaya M, Watanabe A, Sato K, Ito T, Ito N, Sasaki M, Miura M: Effect of suplatast tosilate, a Th2 cytokine inhibitor, on cough-variant asthma. Eur J Clin Pharmacol 2002, 58:171-176.

21. Dicpinigaitis $P V$, Dobkin JB, Reichel J: Antitussive effect of the leukotriene receptor antagonist zafirlukast in subjects with cough-variant asthma. J Asthma 2002, 39:291-297.

22. Ceyhan BB, Karakurt S: Effect of oxolamine on cough sensitivity in COPD patients. Respir Med 2002, 96:61-63.

23. Dicpinigaitis PV, Grimm DR, Lesser M: Baclofen-induced cough suppression in cervical spinal cord injury. Arch Phys Med Rahabil 2000, 81:921-923.

24. Brightling CE, Ward R, Wardlaw AJ, Pavord ID: Airway inflammation, airway responsiveness and cough before and after inhaled budesonide in patients with eosinophilic bronchitis. Eur Respir J 2000, 15:682-686.

25. Dicpinigaitis PV, Dobkin JB, Rauf K, Aldrich TK: Inhibition of capsaicin-induced cough by the gamma-aminobutyric acid agonist baclofen. J Clin Pharmacol 1998, 38:364-367.

26. Shioya T, Ito N, Watanabe A, Kagaya M, Sano M, Shindo T, Miura S, Kimura K, Miura M: Antitussive effect of azelastine hydrochloride in patients with bronchial asthma. Arzneimittelforschung 1998, 48:149-153.

27. Dicpinigaitis PV, Dobkin JB: Antitussive effect of the GABA-agonist baclofen. Chest 1997, 111:996-999.

28. Shioya T, Ito N, Sasaki M, Kagaya M, Sano M, Shindo T, Kashima M, Miura M: Cough threshold for capsaicin increases by azelastine in patients with cough-variant asthma. Pulm Pharmacol 1996, 9:59-62.
29. Fujimura M, Kamio $Y$, Kasahara K, Bando T, Hashimoto T, Matsuda T: Prostanoids and cough response to capsaicin in asthma and chronic bronchitis. Eur Respir J 1995, 8:1499-1505.

30. Hargreaves MR, Benson MK: Inhaled sodium cromoglycate in angiotensin-converting enzyme inhibitor cough. Lancet 1995, 345:13-16

31. Hansson L, Midgren B, Karlsson JA: Effects of inhaled lignocaine and adrenaline on capsaicin-induced cough in humans. Thorax 1994, 49:1166-1168

32. Van Wyck M, Sommers DK, Snyman JR: Effects of glycopyrrolate on capsaicin-induced cough in normal volunteers treated with captopril. Eur J Clin Pharmacol 1994, 46:437-439.

33. Cazzola M, Matera MG, Liccardi G, De Prisco F, D'Amato G, Rossi F: Theophylline in the inhibition of angiotensin-converting enzyme inhibitor-induced cough. Respiration 1993, 60:212-215.

34. Foster G, Yeo WW, Ramsay LE: Effect of sulindac on the cough reflex of healthy subjects. Br J Clin Pharmacol 1991, 31:207-208.

35. McEwan JR, Choudry NB, Fuller RW: The effect of sulindac on the abnormal cough reflex associated with dry cough. J Pharmacol Exp Ther 1990, 255:161-164

36. Choudry NB, Fuller RW, Anderson N, Karlsson JA: Separation of cough and reflex bronchoconstriction by inhaled local anaesthetics. Eur Respir J 1990, 3:579-583.

37. Fuller RW, Karlsson JA, Choudry NB, Pride NB: Effect of inhaled and systemic opiates on responses to inhaled capsaicin in humans. J Appl Physiol 1988, 65:1125-1130.

38. Ryan NM, Birring SS, Gibson PG: Gabapentin for refractory chronic cough: a randomized, double-blind, placebo-controlled trial. Lancet 2012, Epub ahead of print.

39. Yousaf N, Monteiro W, Parker D, Matos S, Birring S, Pavord ID: Long-term low-dose erythromycin in patients with unexplained chronic cough: a double-blind placebo controlled trial. Thorax 2010, 65:1107-1110.

40. Davenport PW, Bolser DC, Vickroy T, Berry RB, Martin AD, Hey JA, Danzig M: The effect of codeine on the urge-to-cough response to inhaled capsaicin. Pulm Pharmacol Ther 2007, 20:338-346.

41. Dicpinigaitis PV, Gayle YE: Effect of the second-generation antihistamine, fexofenadine, on cough reflex sensitivity and pulmonary function. Br J Clin Pharmacol 2003, 56:501-504.

42. Dicpinigaitis PV: Effect of the cyclooxygenase-2 inhibitor celecoxib on bronchial responsiveness and cough reflex sensitivity in asthmatics. Pulm Pharmacol Ther 2001, 14:93-97.

43. Fujimura M, Kamio Y, Myou S, Hashimoto T: Effect of oral mexiletine on the cough response to capsaicin and tartaric acid. Thorax 2000, 55:126-128.

44. Dicpinigaitis PV, Dobkin JB: Effect of zafirlukast on cough reflex sensitivity in asthmatics. J Asthma 1999, 36:265-270.

45. Capon DA, Bochner F, Kerry N, Mikus G, Danz C, Somogyi AA: The influence of CYP2D6 polymorphism and quinindine on the disposition and antitussive effect of dextromethorphan in humans. Clin Pharmaco Ther 1996, 60:295-307.

46. Hansson L, Choudry NB, Karlsson JA, Fuller RW: Inhaled nicotine in humans: effect on the respiratory and cardiovascular systems. J Appl Physiol 1994, 76:2420-2427.

47. Hutchings HA, Eccles R: The opioid agonist codeine and antagonist naltrexone do not affect voluntary suppression of capsaicin induced cough in healthy subjects. Eur Respir J 1994, 7:15-19.

48. O'Connell F, Thomas VE, Fuller RW, Pride NB, Karlsson JA: Effect of clonidine on induced cough and bronchoconstriction in guinea pigs and healthy humans. J Appl Physiol 1994, 76:1082-1087.

49. Fujimura M, Sakamoto S, Kamio Y, Bando T, Kurashima K, Matsuda T: Effect of inhaled procaterol on cough receptor sensitivity to capsaicin in patients with asthma or chronic bronchitis and in normal subjects. Thorax 1993, 48:615-618

50. Choudry NB, Studham J, Harland D, Fuller RW: Modulation of capsaicin induced airway reflexes in humans: effect of monoamine oxidase inhibition. Br J Clin Pharmacol 1993, 35:184-187.

51. Stone RA, Worsdell YM, Fuller RW, Barnes PJ: Effects of 5-hydroxytryptamine and 5-hydroxytryptophan infusion on the human cough reflex. J Appl Physiol 1993, 74:396-401.

52. Fujimura M, Sakamoto S, Kamio Y, Matsuda T: Effects of methacholine induced bronchoconstriction and procaterol induced bronchodilation on cough receptor sensitivity to inhaled capsaicin and tartaric acid. Thorax 1992, 47:441-445. 
53. Ventresca PG, Nichol GM, Barnes PJ, Chung KF: Effect of frusemide on the induction and potentiation of cough induced by prostaglandin $\mathrm{F} 2$ alpha. Br J Clin Pharmacol 1992, 33:514-516.

54. Karlsson JA, Choudry NB, Zackrisson C, Fuller RW: A comparison of the effect of inhaled diuretics on airway reflexes in humans and guinea pigs. J Appl Physiol 1992, 72:434-438.

55. Studham J, Fuller RW: The effect of oral terfenadine on the sensitivity of the cough reflex in normal volunteers. Pulm Pharmacol 1992, 5:51-52.

56. Choudry NB, Gray SJ, Posner J, Fuller RW: The effect of 443C81, a mu opioid receptor agonist, on the response to inhaled capsaicin in healthy volunteers. Br J Clin Pharmacol 1991, 32:633-636.

57. Smith CA, Adamson DL, Choudry NB, Fuller RW: The effect of altering airway tone on the sensitivity of the cough reflex in normal volunteers. Eur Resp J 1991, 4:1078-1079.

58. Choudry NB, McEwan JR, Lavender EA, Williams AJ, Fuller RW: Human responses to inhaled capsaicin are not inhibited by granisetron. Br J Clin Pharmacol 1991, 31:337-339.

59. Hansson L, Choudry NB, Fuller RW, Pride NB: Effect of nedocromil sodium on the airway response to inhaled capsaicin in normal subjects. Thorax 1988, 43:935-936.

60. Dicpinigaitis PV, Colice GL, Goolsby MJ, Rogg Gl, Spector SL, Winther B: Acute cough: a diagnostic and therapeutic challenge. Cough 2009, 5:11.

doi:10.1186/1745-9974-8-10

Cite this article as: Dicpinigaitis: Review: Effect of drugs on human cough reflex sensitivity to inhaled capsaicin. Cough 2012 8:10.

\section{Submit your next manuscript to BioMed Central and take full advantage of:}

- Convenient online submission

- Thorough peer review

- No space constraints or color figure charges

- Immediate publication on acceptance

- Inclusion in PubMed, CAS, Scopus and Google Scholar

- Research which is freely available for redistribution 